\title{
Bacterial Vaginosis Awareness Among Pediatric and Adolescent Age Groups in Saudi Arabia
}

\section{Ettedal A. Aljahdali, MBBCH, SBOG, CBG-OBGYN AFSA}

Department of Obstetrics and Gynecology, Faculty of Medicine

King Abdulaziz University, Jeddah, Saudi Arabia

\section{Correspondence}

Dr. Ettedal A. Aljahdali

P.O. Box 80215, Jeddah 21589, Saudi Arabia

e.M: dr.aljhdali@hotmail.com

Submission: 23 Nov. 2016

Accepted: 13 Dec. 2016

\section{Citation}

Aljahdali EA. Bacterial vaginosis awareness among pediatric and adolescent age groups in Saudi Arabia. JKAU Med Sci 2017; 24 (1): 33-42. DOI: 10.4197/Med. 24.4.4

\begin{abstract}
Bacterial vaginosis has turned into one of the most common medical condition among women here in Saudi Arabia. Several contributing factors, including the lack of knowledge have been affiliated with this infection and yet the cause remains uncertain. The aim of this study is to determine the level of population awareness regarding bacterial vaginosis both in pediatric and adolescent age groups. It also seeks to evaluate the relationship between the outlined causative factors and bacterial vaginosis. A cross sectional descriptive study was conducted using a self-developed questionnaire and was distributed among the participants (adolescent girls, mothers and non-mothers) over a period of four months from December 2013 until March 2014 at King Abdulaziz Hospital, Jeddah, Saudi Arabia. The study revealed that a remarkable number of the mother respondents demonstrated awareness on bacterial vaginosis in pre-pubertal and adolescent age group $(289,96.98 \%)$. The sample of population under the pre-pubertal age group $(122,40.94 \%)$ had higher incidence rates of bacterial vaginosis in comparison with the adolescents and non-mothers $(17,6.25 \%)$. Advanced research is required to better understand the pathological and physiological mechanisms of bacterial vaginosis. Continuing studies are necessary to enhance the accuracy of its diagnosis and modalities of treatment.
\end{abstract}

\section{Keywords}

Bacterial vaginosis; Douching; Gardnerella vaginalis; Anaerobic pathogens; Lactobacilli; Polymicrobial; Gynecologist;

Adolescent; Pre-pubertal

\section{Introduction}

$B$ acterial vaginosis (BV) is an emerging public concern which is characterized by an alteration in the bacterial equilibrium of a woman's vaginal flora. This happens when the number of lactobacilli is reduced, compromising its protective role to maintain the vagina's normal acidity levels. As a result, an overgrowth of anaerobic pathogens occurs manifesting symptoms of a thin vaginal discharge and a fishy vaginal odor ${ }^{[1]}$. Previous findings showed specimen cultures were dominated by Gardnerella vaginalis ( $G$. 
vaginalis) species ${ }^{[2]}$. Apart from species of $G$. vaginalis, several other anaerobic organisms were attributed with $\mathrm{BV}$ thus reaching to a conclusion that $\mathrm{BV}$ is therefore a polymicrobial infection ${ }^{[3]}$. Unfortunately, it remains unclear due to lack of concrete evidence about the main etiologic cause of $B V^{[4]}$.

Based on recent studies, vaginosis is one of the most frequent conditions complained by gynecologic patients who are in the reproductive age ${ }^{[5]}$. Symptoms of vaginal discharge prompted patients to seek medical advice ${ }^{[6]}$.

In a study conducted by Verstraelen et al. ${ }^{[7]}$, it stated that $\mathrm{BV}$ is prevalent among adolescents including girls who never had sexual contacts. Oppositely, Fethers et al. ${ }^{[8]}$ mentioned that BV does not exist in non-sexually experienced women. Currently, researchers cited that it is perceived to be a sexually transmitted infection, although majority of the reported cases were not caused by sexual intercourse ${ }^{[0]}$.

Several risk factors have been associated with BV. According to Brotman et al. ${ }^{[10]}$, douching posed greater risks of disturbing the vaginal flora. Similarly, excessive washing modifies the proportion of good pathogens which enhances the possibility of bad bacteria to thrive ${ }^{[11]}$. Another investigation concluded that multiple sex partners and smoking predisposes a person to acquire the infection ${ }^{[9]}$.

There have been some preventive measures suggested such as avoidance of wearing tight pants and non-cotton underwear, however, it's relation to BV is yet to be proven scientifically, mainly in pre-pubertal and adolescent non-sexually active girls.

This study aspires to provide information about the level of awareness among people living in Saudi Arabia. Likewise, to determine the relativity of the risk factors and preventive measures with BV.

\section{Materials and Methods}

There was a total of 570 respondents who actively took part in answering the questionnaire for this study. Out of those 298 were mothers with pre-pubertal daughters and 272 combined girls and non-mother respondents. It was conducted at King Abdulaziz University Hospital (KAUH) Jeddah, Saudi Arabia and in nearby establishments from December 2013 until March 2014. The surveys were distributed to target participants in KAUH waiting areas of the clinics, within the university, and in the public areas of the aforementioned locations.

\section{Study Design}

A cross-sectional descriptive study was used with the aid of a self-developed questionnaire written in Arabic. The survey was divided into three sub-parts. The first part intended to obtain the participant's demographic data. The second part included questions designed to further evaluate the awareness of this group of population about vaginosis. The last part was outlined to acquire the possible causes of BV.

\section{Inclusion Criteria}

All women and girls who are sexually and non-sexually active, premarital females ages 10 years and above, including female children below 10 years old under the care of their mothers. The age group of adolescent girls is from 10 to 19 years old ${ }^{[12]}$.

\section{Exclusion Criteria}

No exclusion criteria.

\section{Data Analysis}

The statistical analysis was done using the SPSS 16.0 software package. The statistical significance is set at level $p<0.05$.

\section{Results}

Based on the population's (mothers) demographics, it was dominated by participants whose age ranged between 31 and above $(282,94.63 \%)$ as shown in Table 1. A frequency of $284(95.3 \%)$ were Saudi nationals and a greater portion were married $(291,97.7 \%)$. Most of them have kids between 1 to 3 in number $(270,90.6 \%)$.

Almost all of the mothers were highly educated from a university $(281,94.3 \%)$ and were earning above average (284, 95.3\%) (Table 1). Among the 298 mother participants, a total of $289(96.98 \%)$ demonstrated a high level of awareness about BV (Table 2). This was evident based on the number of participants who 
Bacterial Vaginosis Awareness among Pediatric and Adolescent Age Groups in Saudi Arabia E.A. Aljahdali

Table 1. Demographics of mother participants.

\begin{tabular}{|c|c|c|}
\hline Group & Frequency & Percentage (\%) \\
\hline \multicolumn{3}{|l|}{ Age of mother participants } \\
\hline $21-25$ & 4 & $1.34 \%$ \\
\hline $26-30$ & 12 & $4.03 \%$ \\
\hline $31 \&$ Above & 282 & $94.63 \%$ \\
\hline Total & 298 & $100.00 \%$ \\
\hline \multicolumn{3}{|c|}{ Nationality of mother participants } \\
\hline Saudi & 284 & $95.30 \%$ \\
\hline Non-Saudi & 14 & $4.70 \%$ \\
\hline Total & 298 & $100.00 \%$ \\
\hline \multicolumn{3}{|c|}{ Marital Status of mother participants } \\
\hline Married & 291 & $97.70 \%$ \\
\hline Divorced & 4 & $1.30 \%$ \\
\hline Widow & 3 & $1.00 \%$ \\
\hline Total & 298 & $100.00 \%$ \\
\hline \multicolumn{3}{|c|}{ Number of mother participants' kids } \\
\hline $1-3$ & 270 & $90.60 \%$ \\
\hline $4-6$ & 23 & $7.70 \%$ \\
\hline $7-9$ & 5 & $1.70 \%$ \\
\hline Total & 298 & $100.00 \%$ \\
\hline \multicolumn{3}{|c|}{ Educational level of mother participants } \\
\hline Secondary & 1 & $0.33 \%$ \\
\hline High School & 7 & $2.35 \%$ \\
\hline University & 281 & $94.30 \%$ \\
\hline Higher Education & 9 & $3.02 \%$ \\
\hline Total & 298 & $100.00 \%$ \\
\hline \multicolumn{3}{|c|}{ Economic status of mother participants } \\
\hline Below average & 4 & $1.30 \%$ \\
\hline Average & 10 & $3.40 \%$ \\
\hline Above average & 284 & $95.30 \%$ \\
\hline Total & 298 & $100.00 \%$ \\
\hline
\end{tabular}

Table 2. Bacterial vaginosis information based on mother participants' data.

\begin{tabular}{|l|c|c|}
\hline \multicolumn{1}{|c|}{ Group } & Frequency & Percentage (\%) \\
\hline Knowledge of mother participants about bacterial vaginosis & $96.98 \%$ \\
\hline Yes & 289 & $3.02 \%$ \\
\hline No & 9 & $100.00 \%$ \\
\hline Total & 298 \\
\hline Signs of bacterial vaginosis according to mother participants \\
\hline Vaginal discharge & 253 & $84.90 \%$ \\
\hline Pain & 84 & $28.19 \%$ \\
\hline Redness & 90 & $30.20 \%$ \\
\hline Itching & 68 & $22.82 \%$ \\
\hline Rate of mother participants' daughters who had previous infection & \\
\hline Yes & 122 & $40.94 \%$ \\
\hline No & 176 & $59.06 \%$ \\
\hline Total & 298 & $100.00 \%$ \\
\hline Actions done by mother participants whose daughter had infection & \\
\hline Asked a doctor & 80 & $26.85 \%$ \\
\hline Asked friends & 31 & $10.40 \%$ \\
\hline Used previous medication & 46 & $15.44 \%$ \\
\hline Do nothing & 2 & $0.67 \%$ \\
\hline Not Applicable & 176 & $59.06 \%$ \\
\hline
\end{tabular}


answered vaginal discharge $(253,84.90 \%)$ (Table 2) when asked about the signs of BV hence, its primary manifestation.

The percentage of daughters with ages 9 years and below who had infection $(122,40.94 \%)$ was quite less than those who had not been infected $(176,59.06 \%)$ as shown in Table 2. A large portion of those who had history of infection sought consultation from a doctor $(80,26.85 \%)$. There were 46 (15.44\%, p < 0.0005) daughters who had greater risk for infection because they relied on previous medications (Table 2 ).

A huge number of the participants' daughters were perfectly well and didn't have any chronic diseases (289, $96.98 \%)$. The highly preferred type of undergarment and clothing used for their daughters were cotton (280, $93.96 \%)$ and tight pants $(254,85.23 \%)$ (Table 3$)$.

As shown in Table 4, a significant percentage were not using disinfectants for their children (199, 66.78\%), while those who utilized it $(99,33.22 \%)$ marked a frequency use of once per day $(56,18.79 \%)$ (Table 4). Those who are changing underwear at least twice per day were recorded with the highest rate of 136 (45.64\%) (Table 3).

On the other hand, of the 272 combined girls and non-mothers, a total of 95 (34.93\%) participants were between $16-20$ years of age (Table 5$)$. The sample was dominated by Saudis (192, 70.6\%), most were married and sexually active $(165,60.66 \%, p=0.004)$ (Table 5 ).

Similar with the mothers, most of them were educated in the university level $(128,47.06 \%)$ (Table $5)$, however, their economic status were almost entirely below average $(204,75 \%)$.

Oppositely, Table 6 shows that the girls and nonmothers didn't have sufficient knowledge about BV $(143,52.57 \%)$. Based on Table 6 , a very few number were recorded to have had BV $(17,6.25 \%)$.

Table 3. Preferred clothes of mother participants' daughters.

\begin{tabular}{|l|c|c|}
\hline \multicolumn{1}{|c|}{ Group } & Frequency & Percentage (\%) \\
\hline Type of underwear used by mother participants' daughters & $93.96 \%$ \\
\hline Cotton & 280 & $6.04 \%$ \\
\hline Non-cotton & 18 & $100.00 \%$ \\
\hline Total & 298 & $33.56 \%$ \\
\hline Frequency of Changing Underwear & 100 & $45.64 \%$ \\
\hline Once a day & 136 & $20.47 \%$ \\
\hline Twice a day & 61 & $.33 \%$ \\
\hline More than twice per day & 1 & $100.00 \%$ \\
\hline Every 2 days or more & 298 \\
\hline Total & 254 & $85.23 \%$ \\
\hline Response of mother participants when asked if daughter preferred tight pants or clothes \\
\hline Yes & 44 & $14.77 \%$ \\
\hline No & 298 & $100.00 \%$ \\
\hline Total &
\end{tabular}

Table 4. Disinfectants usage rate of mother participants' daughters.

\begin{tabular}{|c|c|c|}
\hline \multicolumn{1}{|c|}{ Group } & Frequency & Percentage (\%) \\
\hline Number of mother participants who use disinfectants for their daughter \\
\hline Yes & 99 & $33.22 \%$ \\
\hline No & 199 & $66.78 \%$ \\
\hline Total & 298 & $100.00 \%$ \\
\hline Frequency of using disinfectants for mother participants' daughters \\
\hline Once & 56 & $18.79 \%$ \\
\hline Twice & 34 & $11.41 \%$ \\
\hline 3 or more & 9 & $3.02 \%$ \\
\hline Not using & 199 & $66.78 \%$ \\
\hline Total & 298 & $100.00 \%$ \\
\hline
\end{tabular}


Bacterial Vaginosis Awareness among Pediatric and Adolescent Age Groups in Saudi Arabia E.A. Aljahdali

Table 5. Demographics of combined girls and non-mother participants.

\begin{tabular}{|c|c|c|}
\hline Group & Frequency & Percentage (\%) \\
\hline \multicolumn{3}{|c|}{ Age of Combined Girls and Non-mothers } \\
\hline $10-15$ & 33 & $12.13 \%$ \\
\hline $16-20$ & 95 & $34.93 \%$ \\
\hline $21-25$ & 88 & $32.35 \%$ \\
\hline $26-30$ & 41 & $15.07 \%$ \\
\hline $31 \&$ Above & 15 & $5.52 \%$ \\
\hline Total & 272 & $100.00 \%$ \\
\hline \multicolumn{3}{|c|}{ Nationality of Combined Girls and Non-mothers } \\
\hline Saudi & 192 & $70.60 \%$ \\
\hline Non-Saudi & 80 & $29.40 \%$ \\
\hline Total & 272 & $100.00 \%$ \\
\hline \multicolumn{3}{|c|}{ Marital status of Combined Girls and Non-mothers } \\
\hline Virgin & 90 & $33.09 \%$ \\
\hline Married (Sexually Active) & 165 & $60.66 \%$ \\
\hline Divorced & 15 & $5.51 \%$ \\
\hline Widow & 2 & $0.74 \%$ \\
\hline Total & 272 & $100.00 \%$ \\
\hline \multicolumn{3}{|c|}{ Educational Level of Combined Girls and Non-mothers } \\
\hline Not Educated & 6 & $2.20 \%$ \\
\hline Primary & 31 & $11.40 \%$ \\
\hline Secondary & 27 & $9.93 \%$ \\
\hline High school & 72 & $26.47 \%$ \\
\hline University & 128 & $47.06 \%$ \\
\hline Higher Education & 8 & $2.94 \%$ \\
\hline Total & 272 & $100.00 \%$ \\
\hline \multicolumn{3}{|c|}{ Economic Status of Combined Girls and Non-mothers } \\
\hline Below average & 204 & $75.00 \%$ \\
\hline Average & 58 & $21.30 \%$ \\
\hline Above average & 10 & $3.70 \%$ \\
\hline Total & 272 & $100.00 \%$ \\
\hline Below average & 204 & $75.00 \%$ \\
\hline Average & 58 & $21.30 \%$ \\
\hline Above average & 10 & $3.70 \%$ \\
\hline
\end{tabular}

Table 6. Knowledge and rate of bacterial vaginosis infection based on girls and non-mother participants.

\begin{tabular}{|c|c|c|}
\hline \multicolumn{1}{|c|}{ Group } & Frequency \\
\hline Knowledge of combined girls and non-mothers about bacterial vaginosis \\
\hline Yes & 129 & $47.43 \%$ \\
\hline No & 143 & $52.57 \%$ \\
\hline Total & 272 & $100.00 \%$ \\
\hline Number of combined girls and non-mothers who had previous infection \\
\hline Yes & 17 & $6.25 \%$ \\
\hline No & 255 & $93.75 \%$ \\
\hline Total & 272 & $100.00 \%$ \\
\hline
\end{tabular}


A greater allocation was using cotton underwear $(238,87.50 \%)$ (Table 7), and tight pants or clothes $(179,65.81 \%)$ as shown in Table 7. A maximal fraction of combined girls and non-mothers were not using vaginal wash $(146,53.68 \%$ ) (Table 8$)$. For those who used disinfectants $(126,46.3 \%)$, a larger number were using it once per day only $(65,23.90 \%$ ) (Table 8). Based on Table 7, it shows that there were $119(43.75 \%)$ who stated that they change underwear at least once a day.

An enormous portion mentioned that they weren't masturbating $(256,94.12 \%)$ while $16(5.88 \%)$ admitted that they do sometimes (Table 9).

\section{Discussion}

Although the mothers showed higher level of awareness about BV $(289,96.98 \%)$, their daughters who were in the pre-pubertal age group, were the ones who had higher incidence rates of BV $(122,40.94 \%)$, contrary with the infected adolescents and non-mothers (17, $6.25 \%)$ who had limited information (143, 52.57\%). This can be correlated with the pathophysiological aspect of pre-pubertal girls where the levels of estrogen is low, resulting to fewer or zero number of lactobacilli responsible in maintaining alkalinity of the vagina ${ }^{[13]}$, therefore allowing harmful bacteria to dominate

Table 7. Preferred clothes of combined girls and non-mother participants.

\begin{tabular}{|l|c|c|}
\hline \multicolumn{1}{|c|}{ Group } & Frequency & Percentage (\%) \\
\hline Type of underwear used by combined girls and non-mothers & $87.50 \%$ \\
\hline Cotton & 238 & $12.50 \%$ \\
\hline Non-cotton & 34 & $100.00 \%$ \\
\hline Total & 272 & $43.75 \%$ \\
\hline Frequency of changing underwear & 119 & $34.93 \%$ \\
\hline Once a day & 95 & $20.59 \%$ \\
\hline Twice a day & 56 & $0.73 \%$ \\
\hline More than twice per day & 2 & $100.00 \%$ \\
\hline Every 2 days or more & 272 & $65.81 \%$ \\
\hline Total & 179 & $34.19 \%$ \\
\hline Preferred pants or clothes by combined girls and non-mothers & $100.00 \%$ \\
\hline Tight & 93 & \\
\hline Non-tight & 272 & \\
\hline Total & & \\
\hline
\end{tabular}

Table 8. Disinfectants usage rate of combined girls and non-mother participants.

\begin{tabular}{|c|c|c|}
\hline \multicolumn{1}{|c|}{ Group } & Frequency & Percentage (\%) \\
\hline Number of combined girls and non-mothers who are using disinfectants & $46.32 \%$ \\
\hline Yes & 126 & $53.68 \%$ \\
\hline No & 146 & $100.00 \%$ \\
\hline Total & 272 & $23.90 \%$ \\
\hline Combined girls and non-mothers' frequency of using disinfectants & $18.01 \%$ \\
\hline Once & 65 & $4.41 \%$ \\
\hline Twice & 49 & $53.68 \%$ \\
\hline 3 or more & 12 & $100.00 \%$ \\
\hline Not using & 146 & \\
\hline Total & 272 & \\
\hline
\end{tabular}

Table 9. Frequency of masturbation of combined girls and non-mother participants.

\begin{tabular}{|l|c|c|}
\hline \multicolumn{1}{|c|}{ Group } & Frequency & Percentage (\%) \\
\hline Never & 256 & $94.12 \%$ \\
\hline Sometimes & 16 & $5.88 \%$ \\
\hline Total & 272 & $100.00 \%$ \\
\hline
\end{tabular}


and increase their susceptibility for infection. Using previous medications to treat BV posed higher risks to acquire the infection $(p<0.0005)$ (as shown in Table 10). Women engaged in marital and premarital sexual activities $(p=0.004)$ revealed high significance with BV (Table 11).

As shown in Table 12, vaginal douching and its frequency were also greatly related to BV $(p=0.004, p$ $=0.034$ respectively).
This was evidenced by the rates of infection for all age groups wherein the number of non-infected daughters $(176,59.06 \%)$ and girls or non-mothers $(255$, $93.75 \%)$ were relatively high, as the majority of them were not using vaginal disinfectants $(199,66.78 \%$ and $146,53.68 \%$ respectively).

Oppositely, wearing tight pants $(p=0.736, p=$ 0.248 ) and cotton underwear ( $p=0.498, p=0.345$ ) among all age groups were not associated with BV.

Table 10. Cross-tabulation of statistics between the sample's reliance on previous medication and data of having previous infection.

\begin{tabular}{|c|c|c|c|c|c|}
\hline \multirow{2}{*}{\multicolumn{3}{|c|}{ P-VALUE $<0.0005$}} & \multicolumn{2}{|c|}{ Did your daughter had any infection before? } & \multirow{2}{*}{ Total } \\
\hline & & & Yes & No & \\
\hline \multirow{4}{*}{ Used Previous Medication } & \multirow{2}{*}{ No } & Count & 76 & 176 & 252 \\
\hline & & $\%$ Used previous medication & $30.16 \%$ & $69.84 \%$ & $100.00 \%$ \\
\hline & \multirow{2}{*}{ Yes } & Count & 46 & 0 & 46 \\
\hline & & $\%$ Used previous medication & $100.00 \%$ & $0.0 \%$ & $100.00 \%$ \\
\hline \multirow{2}{*}{\multicolumn{2}{|c|}{ Total }} & Count & 122 & 176 & 298 \\
\hline & & $\%$ Used previous medication & $40.94 \%$ & $59.06 \%$ & $100.00 \%$ \\
\hline
\end{tabular}

Table 11. Cross-tabulation of statistics between the sample's marital status and data of having previous infection.

\begin{tabular}{|c|c|c|c|c|c|}
\hline \multirow{2}{*}{\multicolumn{3}{|c|}{ P-VALUE $=0.004$}} & \multicolumn{2}{|c|}{ Did you have any infection before? } & \multirow{3}{*}{$\begin{array}{c}\text { Total } \\
90\end{array}$} \\
\hline & & & Yes & No & \\
\hline \multirow{6}{*}{ Marital Status } & \multirow{2}{*}{ Virgin } & Count & 2 & 88 & \\
\hline & & $\%$ Marital Status & $2.22 \%$ & $97.78 \%$ & $100.00 \%$ \\
\hline & \multirow{2}{*}{ Married } & Count & 11 & 154 & 165 \\
\hline & & $\%$ Marital Status & $6.67 \%$ & $93.33 \%$ & $100.00 \%$ \\
\hline & \multirow{2}{*}{ Divorced/Widow } & Count & 4 & 13 & 17 \\
\hline & & $\%$ Marital Status & $23.53 \%$ & $76.47 \%$ & $100.00 \%$ \\
\hline \multirow{2}{*}{\multicolumn{2}{|c|}{ Total }} & Count & 17 & 255 & 272 \\
\hline & & $\%$ Marital Status & $6.25 \%$ & $93.75 \%$ & $100.00 \%$ \\
\hline
\end{tabular}

Table 12. Comparison of results based on the group of mothers with daughters and group of girls and non-mothers based on frequency and use of disinfectants.

\begin{tabular}{|l|c|l|c|}
\hline \multicolumn{2}{|c|}{$\begin{array}{c}\text { Mothers with Pre-Pubertal Daughters } \\
(\mathrm{N}=298)\end{array}$} & \multicolumn{2}{c|}{$\begin{array}{c}\text { Girls and Non-Mothers } \\
\text { (N=272) }\end{array}$} \\
\hline Do you use disinfectants for your daughter & Frequency & Do you use disinfectants & $126,46.32 \%$ \\
\hline Yes & $99,33.22 \%$ & Yes & $146,53.68 \%$ \\
\hline No & $\begin{array}{c}199,66.78 \% \\
(p=0.004)\end{array}$ & No & $272,100.00 \%$ \\
\hline Total & $298,100.00 \%$ & Total & Percentage \\
\hline Frequency of Use & Percentage & Frequency of Use & $65,23.90 \%$ \\
\hline Once & $\begin{array}{l}56,18.79 \% \\
(p=0.034)\end{array}$ & Once & $49,18.00 \%$ \\
\hline Twice & $34,11.40 \%$ & Twice & $12,4.40 \%$ \\
\hline 3 or more & $9,3.00 \%$ & 3 or more & $146,53.70 \%$ \\
\hline Not using & $199,66.80 \%$ & Not using & $272,100.00 \%$ \\
\hline Total & $298,100.00 \%$ & Total & \\
\hline
\end{tabular}


Table 13. Comparison of results based on the group of mothers with daughters and group of girls and non-mothers based on preferred clothes, underwear and frequency of changing undergarments.

\begin{tabular}{|c|c|c|c|}
\hline \multicolumn{2}{|c|}{$\begin{array}{l}\text { Mothers with pre-pubertal daughters } \\
(\mathrm{N}=298) \\
\end{array}$} & \multicolumn{2}{|c|}{$\begin{array}{l}\text { Girls and Non-Mothers } \\
\qquad(\mathrm{N}=272)\end{array}$} \\
\hline Type of underwear & Frequency & Type of underwear & Frequency \\
\hline Cotton & $\begin{array}{c}280,93.96 \% \\
(p=0.498)\end{array}$ & Cotton & $\begin{array}{c}238,87.50 \% \\
(p=0.345)\end{array}$ \\
\hline Does daughter prefer tight pants & Frequency & Does daughter prefer tight pants & Frequency \\
\hline Yes & $\begin{array}{c}254,85.23 \% \\
(p=0.736)\end{array}$ & Yes & $\begin{array}{c}179,65.81 \% \\
(p=0.248)\end{array}$ \\
\hline Frequency of changing underwear & Percentage & Frequency of changing underwear & Percentage \\
\hline Once a day & $100,33.60 \%$ & Once & $\begin{array}{c}119,43.75 \% \\
(p=0.825)\end{array}$ \\
\hline Twice & $\begin{array}{c}136,45.64 \% \\
(p=0.247)\end{array}$ & Twice a day & $95,34.90 \%$ \\
\hline More than twice per day & $61,20.50 \%$ & More than twice per day & $56,20.60 \%$ \\
\hline Every 2 days or more & $1,0.30 \%$ & Every 2 days or more & $2,0.70 \%$ \\
\hline Total & $298,100.00 \%$ & Total & $272,100.00 \%$ \\
\hline
\end{tabular}

Additionally, poor hygiene did not show direct relation with the infection $(p=0.247, p=0.825)$ (Table 13).

\section{Conclusion and Recommendation}

Bacterial vaginosis infection is not only confined among adolescents and women who are in their reproductive age, this study showed that pre-pubertal females are also inclined to have BV. Furthermore, since sexual activity predisposes a person to transmit and acquire infection, safe sex practices are highly advised.

As there are few proven measures to counteract the condition, it is highly recommended to seek consultation from a healthcare provider. Selfmedication is discouraged without a definite diagnosis of the reported signs and symptoms.

Moreover, continuing analysis and experimentation are proposed towards a breakthrough on BV interpretation and regimen options. One great suggestion would be to probe the possibility of attributing weather conditions with BV, specifically in humid places such as the middle east. This can be performed by way of culture sampling through vaginal swab.

Ultimately, a profound method for educating the people would still be the best tool for its early prevention. There is a major need to strengthen the campaign for awareness, highlighting the latest information about BV.

\section{Conflict of Interest}

The author has no conflict of interest.

\section{Disclosure}

The author did not receive any type of commercial support either in forms of compensation or financial for this study. The author has no financial interest in any of the products or devices, or drugs mentioned in this article.

\section{Ethical Approval}

Obtained.

\section{References}

[1] [No authors listed]. Bacterial vaginosis. Centers for Disease Control and Prevention. 2015. Accessed from <https:// www.cdc.gov/std/tg2015/bv.htm>.

[2] Machado D, Castro J, Palmeira-de-Oliveira A, Martinez-deOliveira J, Cerca N. Bacterial vaginosis biofilms: challenges to current therapies and emerging solutions. Front Microbiol 2015; 6:1528.

[3] Sobel JD. Bacterial vaginosis. Annu Rev Med 2000; 51: 349-356.

[4] Onderdonk AB, Delaney ML, Fichorova RN. The human microbiome during Bacterial Vaginosis. Clin Microbiol Rev 2016; 29(2): 223-238.

[5] Bautista CT, Wurapa E, Sateren WB, Morris S, Hollingsworth $B$, Sanchez JL. Bacterial vaginosis: a synthesis of the literature 
on etiology, prevalence, risk factors, and relationship with chlamydia and gonorrhea infections. Mil Med Res 2016; 3: 4.

[6] Mascarenhas RE, Machado MS, Costa e Silva BF, Pimentel RF, Ferreira TT, Leoni FM, Grassi MF. Prevalence and risk factors for bacterial vaginosis and other vulvovaginitis in a population of sexually active adolescents from Salvador, Bahia, Brazil. Infect Dis Obstet Gynecol 2012; 2012: 378640.

[7] Verstraelen $H$, Verhelst $R$, Vaneechoutte $M$, Temmerman $M$. The epidemiology of bacterial vaginosis in relation to sexual behaviour. BMC Infect Dis 2010; 10: 81.

[8] Fethers KA, Fairley CK, Morton A. Early sexual experiences and risk factors for bacterial vaginosis. J Infect Dis 2009; 200(1): 1662-1670.

[9] Sobel JD. Patient education: Bacterial vaginosis (Beyond the Basics). 2015. Accessed from <https://www.uptodate. com/contents/bacterial-vaginosis- beyond-the-basics>.

[10] Brotman RM, Klebanoff MA, Nansel TR, Andrews WW, Schwebke JR, Zhang J, Yu KF, Zenilman JM, Scharfstein DO. A longitudinal study of vaginal douching and bacterial vaginosis - a marginal structural modeling analysis. Am J Epidemiol 2008; 168(2): 188-196.

[11] Paterson S. Bacterial vaginosis. June 2017. Accessed from $<$ https://www.std-gov.org/stds/bacterial_vaginosis.htm>.

[12] Dowdy DW and Chaisson RE. Adolescent health. World Health Organization. 2017. Accessed from <http://www. who.int/topics/adolescent_health/en/>.

[13] Lippincott WW. Vulvovaginitis, prepubescent. Unbound Medicine. 2017. Accessed from <https://www. unboundmedicine.com/5minute/view/5-Minute-ClinicalConsult/116651/all/Nulvovaginitis__Prepubescent>. 


\section{الاتهابات المهبليه ومدى وعي المجتمع لحدوثها لاى الاطفال والمراهقين في المي المملكة العربيه السمعابه الميليه ومديه}

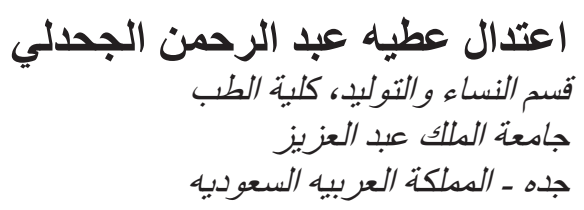

المستخطص. اصبحت الالتهابات النسائية المهبلية من المشاكل الثائعة في المملكة وهناك العديد من العو امل المساعدة لحدوثها

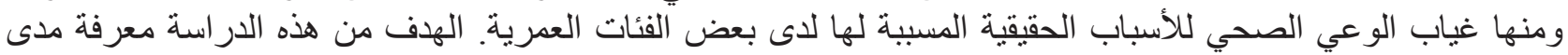

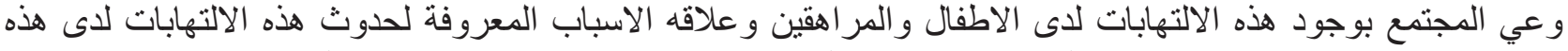

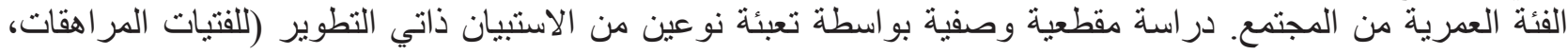

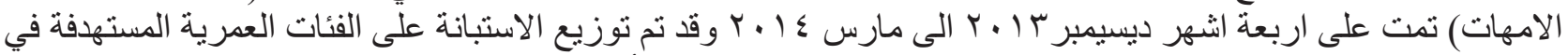

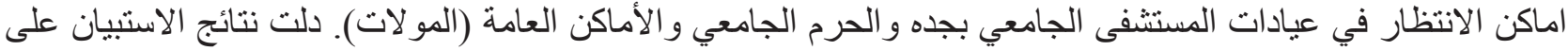

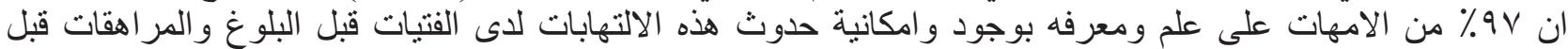

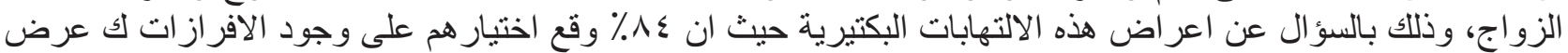

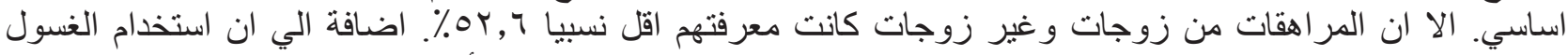

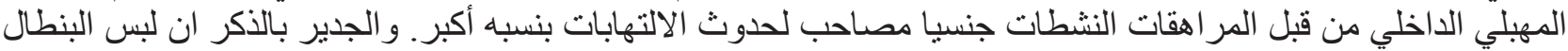

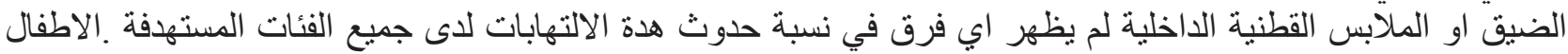

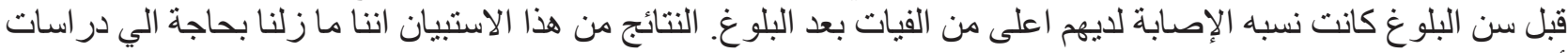

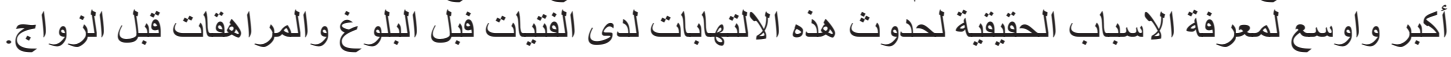

